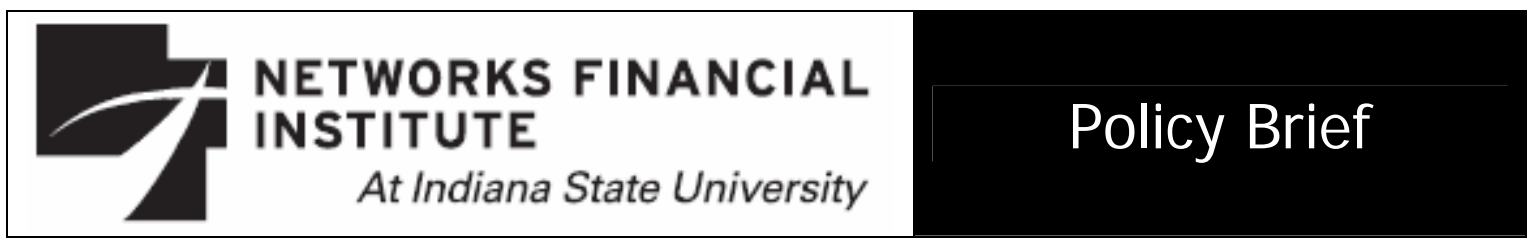

2008-PB-05

May 2008

\title{
Interest on Reserves: Implications for Banking and Policymaking David VanHoose
}

Abstract: This policy brief evaluates the banking and policy implications of 2006 Congressional legislation authorizing the Federal Reserve to pay interest on reserves held at Federal Reserve banks beginning in October 2011. This upcoming policy change has received remarkably little attention from the financial media, yet it promises to have effects along several dimensions. Likely to be impacted are total reserves held by depository institutions, the interest sensitivities of these institutions' asset holdings, balances in sweep accounts managed by depository institutions, and depository institutions intraday overdrafts of their reserve accounts at Federal Reserve banks. In addition, the authorization to pay interest on reserves broadens the set of tools of monetary policy available to the Fed. Finally, this policy change strengthens the case for significant reductions in, or possibly elimination of, reserve requirements on U.S. depository institutions.

About the Author: David VanHoose is a Senior Fellow at Networks Financial Institute. VanHoose earned his Ph.D. at the University of North Carolina at Chapel Hill and is currently the Herman W. Lay Professor of Private Enterprise and Professor of Economics at the Hankamer School of Business at Baylor University. He has published articles in such professional journals as the Quarterly Journal of Economics, the International Economic Review, the Southern Economic Journal, the Journal of Money, Credit, and Banking, Economic Inquiry, and the Scandinavian Journal of Economics.

Keywords: Interest on reserves, intraday overdrafts, sweep accounts.

\section{J EL Codes: G28, E51}

The views expressed are those of the individual author and do not necessarily reflect official positions of Networks Financial Institute. Please address questions regarding content to David VanHoose at

David_VanHoose@baylor.edu. Any errors or omissions are the responsibility of the author.

NFI working papers and other publications are available on NFI's website

(www.networksfinancialinstitute.org). Click "Research" and then "Publications/Papers." 


\section{Interest on Reserves: Implications for Banking and Policymaking David VanHoose}

\section{Introduction}

During past years, various proposals were offered that advocated the payment of interest on reserves that depository institutions-commercial banks, savings institutions, and credit unions - hold at Federal Reserve banks. Most arguments offered in favor of this idea, however, fell on deaf ears, and proposals for the Federal Reserve to pay interest on reserves languished in Congress.

Recently, however, Congress suddenly changed the rules of the game for depository institutions and the Fed. Under legislation passed in 2006, the Fed will be authorized to pay interest on reserves beginning in the fall of 2011. This policy brief briefly surveys the historical development of ideas that culminated in the new legislative authority for payment of interest on reserves and examines the likely implications for the banking industry and Federal Reserve monetary policy.

\section{Interest on Reserves: Transformation of An Old Idea into Policy}

The payment of explicit interest on reserves held by U.S. banks is not a new idea. As discussed by Weiner (1986), prior to passage of the Federal Reserve Act in 1913, U.S. banking laws permitted nationally chartered commercial banks to include correspondent balances earning pecuniary interest as legal reserves for purposes of meeting reserve requirements. In addition, individual state authorities also permitted state-chartered commercial banks to include interest-bearing correspondent balances as legal reserves, and some also allowed state banks to count interest-bearing government securities. 
The Federal Reserve Act did not authorize banks to use of interestbearing correspondent balances or government securities as legal reserves, nor did it explicitly grant Federal Reserve authority to pay interest on banks' reserve balances at Federal Reserve banks. Toma (1999, p. 102) suggests that this was a conscious Congressional decision "to satisfy a revenue requirement by raising revenue from a number of sources, including a levy on money issue." Thus, by requiring banks to hold non-interest-bearing reserves, Congress raises implicit taxes-namely, Federal Reserve interest earnings net of operating expenses that are passed along to the U.S. Treasury each year.

When market interest rates drifted upward during the 1970s, so did the opportunity cost of satisfying reserve requirements established by the Federal Reserve. During that decade, more than 500 banks withdrew from membership in the Federal Reserve System. In an effort to halt further membership erosion, Federal Reserve officials offered proposals for explicit payment of interest on banks' reserve balances or, alternatively, permitting banks to meet reserve requirements by investing in a Federal Reserve portfolio of government securities [Miller (1978); Klein (1980)].

These proposals met with a cool reception in Congress, however. Indeed, following an initial exchange of correspondence between Senator William Proxmire (1978) and Fed chair G. William Miller, in June 1978, Proxmire and Representative Henry Reuss (1978) wrote to Miller:

Whatever the primary motivation may be for paying interest on reserve balances, we want to make our position clear and unequivocal. We are totally and unalterably opposed to any plan, proposal, or draft regulation which purports to authorize the payment of interest on reserve balances without specific legislative approval from the Congress. We believe unilateral action by the Board to pay interest on reserve balances would constitute a blatant usurpation of 
Congressional powers and would raise profound questions about the continued independence of the Fed.

Ultimately, Congress addressed the Fed's membership problem by passing the Depository Institutions Deregulation and Monetary Control Act (DIDMCA) of 1980. Even as this legislation reduced required reserve ratios at many institutions, it imposed a requirement for all banks and other depository institutions to hold non-interest-bearing reserves under requirements established by the Federal Reserve. Thus, the DIDMCA ensured that commercial banks that were members of the Federal Reserve System could no longer escape the opportunity cost of those requirements by ending their Fed membership. As indicated in Figure 1, during the latter part of the 1980s, reserves held by depository institutions at Federal Reserve Banks increased as this uniform reserve requirement became binding, before dropping slightly during the early 1990s following a reduction in the required reserve ratio from 12 percent to 10 percent.

Figure 1: Reserve Balances at Federal Reserve Banks Source: Board of Governors of the Federal Reserve System

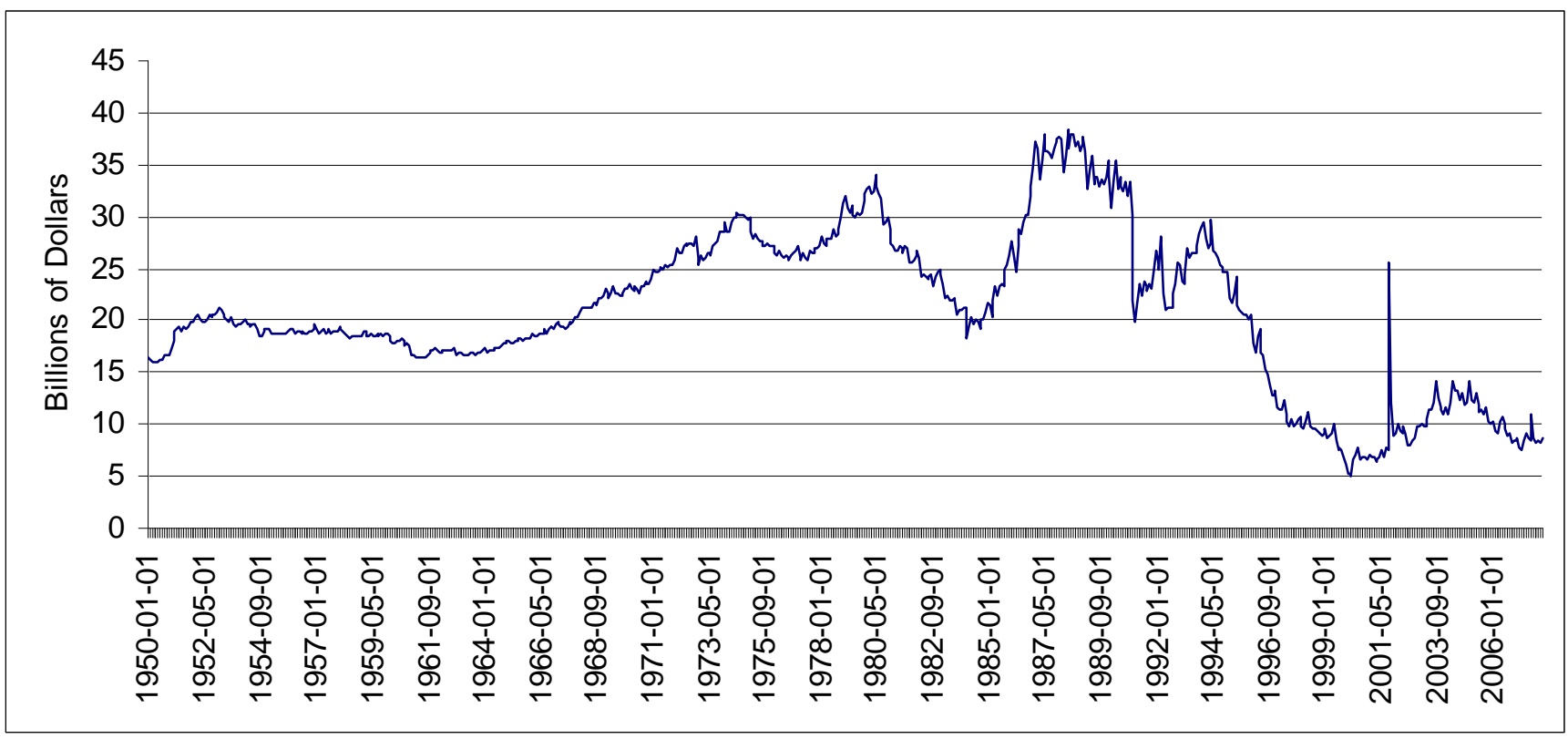


At the time that the DIDMCA was passed, the Fed utilized nonborrowed reserves as its primary operating instrument of monetary policy. Under this operating procedure, reserve requirements can be an important factor influencing the magnitude of effects that Fed policy actions (such as open market operations or discount rate changes) have on the quantity of money in circulation and on market interest rates. Hence, framers of the DIDMCA undoubtedly viewed giving the Fed the power to establish uniform reserve requirements as strengthening the central bank's hands in conducting monetary policy.

As economists [see, for instance, McCallum and Hoehn (1983)] later realized, however, the system of lagged reserve requirements in place at that time weakened the Fed's nonborrowed-reserves-oriented procedure: Because required reserves were based on deposits at banks two weeks earlier, the Fed effectively had to provide sufficient reserves for banks to meet their reserve requirement after the fact. Although the Federal Reserve System had switched to a system of more nearly contemporaneous reserve requirements in 1984, by then Fed monetary policymakers had begun targeting borrowed reserves instead [see Thornton (1988) and VanHoose (1990)]. This borrowed-reserves targeting procedure amounted to an inefficiently indirect federal-funds-rate targeting procedure, and by the end of the 1980s the Fed had begun directly targeting the federal funds rate instead, a policy it has continued to the present day. Furthermore, in 1998 the Fed switched back to the previous system of lagged reserve requirements.

Thus, within a few short years after passage of the DIDMCA, any monetary policy justification for uniform reserve requirements on depository institutions had been undercut by the Fed's changes in its 
monetary policy procedures. Ultimately, therefore, the only remaining rationales for the imposition of an equal implicit reserve tax on all depository institutions $\mathrm{w}$ the elimination of a significant incentive for Fed member banks to exit the Federal Reserve System.

Suggestions to pay interest on the enlarged stock of required reserves at Federal Reserve banks were advanced in the 1980s [see, for instance, New York Times (1991) and Dixon (1991)]. Nevertheless, no formal proposals emerged, and the idea languished. In recent years, Fed interest payments on reserves have been limited to implicit interest in the form of credits that the Fed has extended to depository institutions on holdings of required clearing balances (also known as contractual clearing balances) that institutions hold in anticipation of check clearings or wire transfers that otherwise could generate reserve account overdrafts. Depository institutions have been able to apply these credits toward offsetting the cost of using Federal Reserve payments services.

One might ask why the Fed has maintained a significant legal reserve requirement given the fact that the monetary policy usefulness of reserve requirements was emasculated by its own policy decisions. This question will be considered in section 5 . The fact is, however, that depository institutions developed their own answer, which was to reduce their required reserves via a regulatory loophole. In the early 1990s, a few institutions discovered that laws permitting institutions to establish deposit accounts allowing shifts of funds from nonreservable savings deposit accounts to transactions deposit accounts, subject to reserve requirements for purpose of automatic overdraft protection, did not prohibit a reversal of the funds flow. Consequently, these institutions began shifting funds from customers' transactions accounts into their savings accounts, thereby 
lowering average balances in the former and hence the amount of measured reservable deposits. These were the first so-called sweep accounts-accounts that "sweep" funds from transactions deposit accounts into savings accounts and thereby reduce required reserves of depository institutions. As indicated in Figure 2, in 1994, balances in sweep accounts were slightly over $\$ 5$ billion. Today sweep account balances exceed $\$ 760$ billion, which amounts to more than 55 percent of the M1 measure of the U.S. money stock. [See Dutkowsky and Cynamon (2003), Cynamon, et al. (2006), Dutkowsky, et al. (2006), and Jones et al. (2005 and Forthcoming) for analyses of the impacts of sweep accounts on monetary aggregates.]

\section{Figure 2: Balances in Sweep Accounts at U.S. Depository Institutions Source: Board of Governors of the Federal Reserve System}

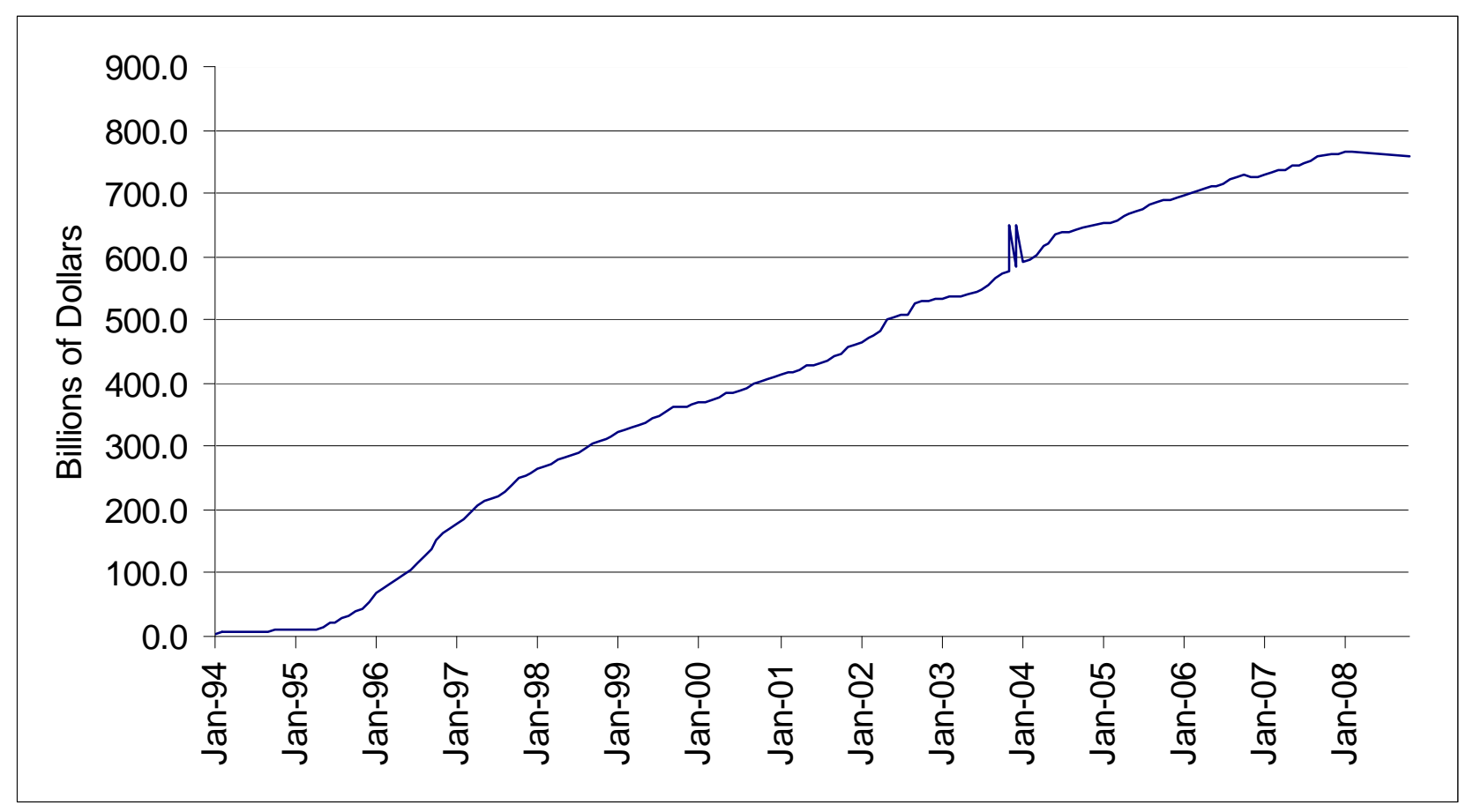


The shifting of so many funds away from reservable transactions deposits to nonreservable savings deposits has generated a significant reduction in the level of reserve balances that depository institutions hold at Federal Reserve banks. As shown in Figure 1, these balances totaled about $\$ 30$ billion in 1994 but average less than $\$ 9$ billion today.

When sweep account balances grew rapidly in the 1990s, there was concern among some Fed policymakers that a relative paucity of reserves held at Federal Reserve banks could hinder the Fed's ability to maintain its interest-rate target. The basic idea was that institutions holding smaller reserve balances would exhibit less interest-sensitive reserve demand, so that variations in reserve supply could generate harder-to-contain volatility of market interest rates. As noted by VanHoose and Humphrey (2001), however, depository institutions with lower reserve balances also have an increased incentive to maintain more stable reserve levels. Indeed, VanHoose and Humphrey show that during the years following the creation of sweep accounts, the federal funds rate was no more volatile than it had been in previous years.

Nevertheless, depository institutions expend resources in operating sweep programs. These expenses boost their costs and thereby reduce returns earned by shareholders and depositors. Thus, even though the monetary policy implications of sweep accounts under the Fed's interestrate-targeting procedure are likely benign, their existence generates an opportunity cost for society. The resources depository institutions devote to managing sweep accounts in order to reduce their legal reserve requirements could be put to alternative uses. Furthermore, the required reserve balances that depository institutions continue to hold earn zero interest, and these funds remain subject to an implicit tax on owners of 
depository institutions and their depositors.

Congressional interest in reducing regulatory burdens on financial institutions suddenly blossomed into action on September 30, 2006, when Congress passed the Financial Services Regulatory Relief Act. This legislation's numerous sections address diverse issues, including items such as giving national banks more flexibility in payment of dividends, increasing the legal maturity limit on federal credit union loans from 12 to 15 years, raising minimum levels of assets required to exempt small depository institutions from certain regulations, and clarifying the authority of state banking regulators over state-chartered banks.

Another of the many sections of the act, Section 201, addresses the payment of interest on reserves depository institutions hold at Federal Reserve banks. This section authorizes the Fed to pay interest on reserves beginning in October 2011. It adds language amending the Federal Reserve Act as follows:

In general. - Balances maintained at a Federal Reserve bank by or on behalf of a depository institution may receive earnings to be paid by the Federal Reserve bank at least once each calendar quarter, at a rate or rates not to exceed the general level of short-term interest rates.

This section of the law also gives the Fed's Board of Governors authority to prescribe regulations concerning how such interest earnings will be distributed and to determine responsibilities of depository institutions and other parties in the crediting of the interest payments.

Clearly, Congress has granted the Fed the discretion to determine what rate of interest to pay on a quarterly basis. The only constraint that the Fed faces is that it is not to offer a rate that exceeds the "general level of short-term interest rates." Thus, the 2006 law goes beyond previous 
suggestions and proposals for interest payments on reserves, which had applied to interest on required reserves. Section 201 of the Financial Services Regulatory Relief Act applies to all reserves that depository institutions hold with Federal Reserve banks. Hence, reserve balances that depository institutions voluntarily hold at Federal Reserve banks over and above those required (commonly called excess reserves) will-barring any discretionary Fed rules to the contrary -also be eligible for interest payments.

\section{Banking Implications of Interest on Reserves}

How will the payment of interest on reserve balances at Federal Reserve banks affect the operations of depository institutions? Of course, in the absence of any clearly specified Fed rules for how it will pay interest beginning in the autumn of 2011, quantitative estimates are infeasible. It is possible, however, to offer a qualitative assessment of the likely effects of moving from a longstanding zero-interest environment to a positive-interest regime.

Naturally, the most obvious effect of the payment of interest on reserves will be to reduce the incentive for banks to economize on holding reserves at Federal Reserve banks. The opportunity cost of the present zerointerest restriction on reserve holdings will decrease, so depository institutions will have a smaller incentive to sweep funds from transactions accounts to savings accounts. Thus, the growth of sweep accounts, which Figure 2 indicates has already slowed, should decline further. If the interest payment on reserves is sufficiently high relative to market interest rates, it is even possible that balances in sweep accounts could begin to shrink. Nevertheless, it seems likely that sweep accounts will remain a fixture of U.S. banking as long as the interest payment on reserves lies below a market 
rate of return, resulting in a positive opportunity cost of holding required reserves.

Furthermore, payment of interest on reserves is likely to give many depository institutions a greater incentive to voluntarily hold larger average balances of excess reserve at Federal Reserve banks. Certainly, lending such reserves at market rates in overnight markets, such as the federal funds market, would continue to generate higher interest returns. If the differential between the market interest rate and the rate paid on reserves held at Federal Reserve banks is sufficiently small, however, in some circumstances depository institution managers are likely to decide that the opportunity cost of time and other resources that might be devoted to arranging an overnight transaction exceed the benefit in the form of this interest differential.

Clearly, the actual effects of interest payments on required and excess reserves on actual levels of both types of reserve balances and on sweep programs will hinge critically on the differential between the market interest rate and the rate paid on reserves. The qualitative outcome, however, should be higher levels of both required and excess reserves and a reduction in growth of or perhaps even levels of deposits in sweep accounts.

Payment of interest on reserves should generate several other impacts on banking markets. As noted by Ennis and Weinberg (2007), an increase in depository institution reserves should relieve intraday liquidity pressures and thereby generate a decrease in so-called "daylight credit." As has been long recognized (see Federal Reserve Payment System Task Force, 1988), because the Fed guarantees the finality of intraday federal funds and book-entry-security transactions on its Fedwire payment system, it effectively extends intraday loans - that is, daylight credit - to depository 
institutions transmitting payments that temporarily - for minutes or even hours-exceed the balances held in their accounts at Federal Reserve banks. Since 1994 the Fed has charged explicit interest fees to institutions that overdraw their reserve accounts above deductibles. Imposition of fees on daylight credit extended on Fedwire generated a sharp reduction in average (based on 18-hour periods) real overdrafts of accounts at Federal Reserve banks from about $\$ 100$ billion at the end of 1993 (in 2005 dollars) to about half that level in early 1994. As Figure 3 indicates, inflation-adjusted peak and average overdrafts remained stable through the 1990s and into the early 2000s but have gradually been increasing since 2002. Today, average depository institution overdrafts are once again above an inflation-adjusted level of $\$ 100$ billion. Thus, total overdrafts have returned in the late 2000s to inflation-adjusted levels that had generated concerns about significant Fed exposure to payment-system risks back in the late 1980s and early 1990s when overdraft fees were first contemplated and then imposed.

Figure 3: Inflation-Adjusted Peak and Average Daylight Overdrafts at U.S. Depository Institutions

Source: Board of Governors of the Federal Reserve System

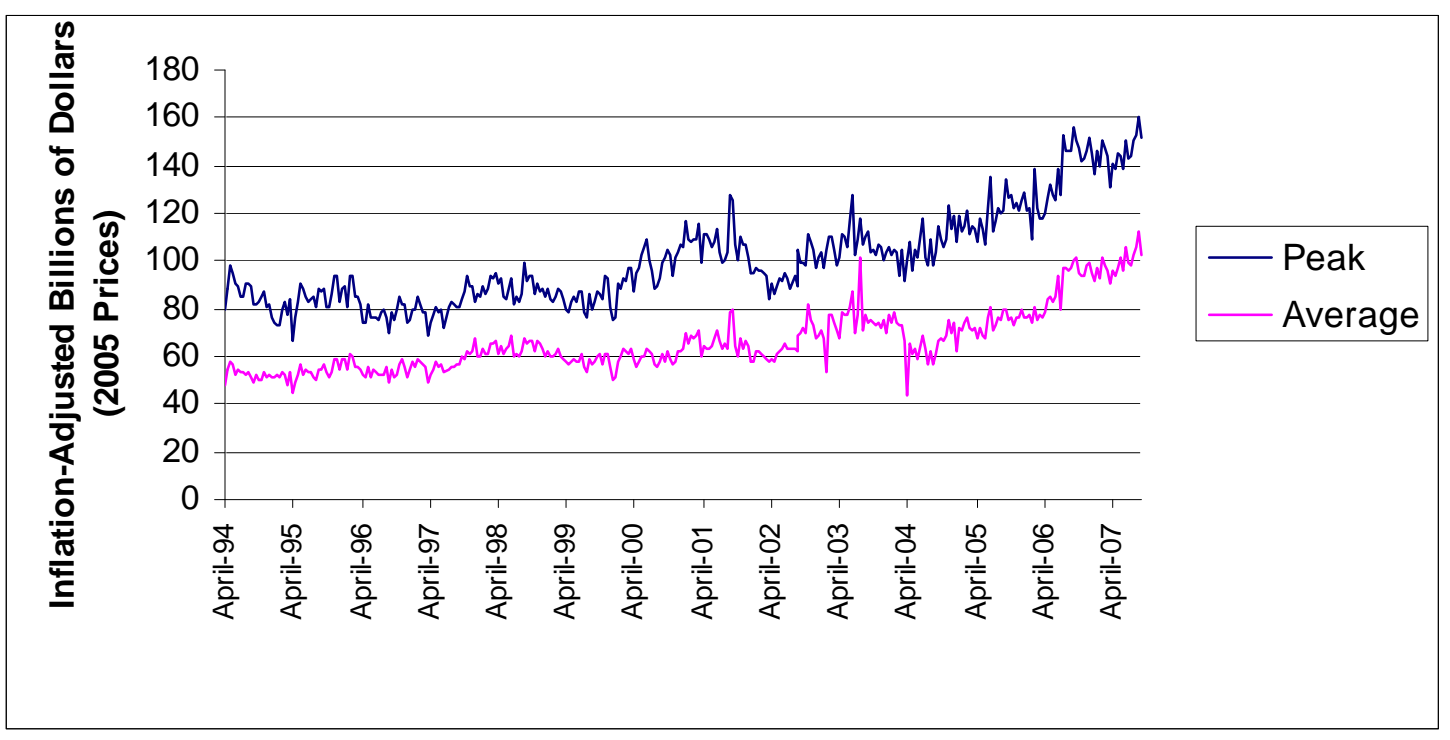


An increased level of reserves generated by payment of interest on reserve balances at Federal Reserve banks undoubtedly would reduce the incentive for depository institutions to overdraw their accounts during the day. Thus, a possible byproduct from the payment of interest on reserves could be a leveling off, and potentially even a reversal, of the recent upward drift in depository institutions' intraday overdrafts depicted in Figure 3, thereby reducing the Fed's exposure to risks.

\section{Implications for Monetary Policymaking}

In the late 1980s, Federal Reserve Board Governor Wayne Angell proposed paying interest on required reserves as part of a plan for addressing the Fed's perceived exposure to risk arising from depository institutions' intraday overdrafts of their reserve accounts. Specifically, Angell suggested charging a penalty rate-an interest fee above prevailing market interest rates-on both Fed discount window loans and intraday overdrafts but simultaneously paying a rate of interest on reserves set below market interest rates. A consequence, Angell suggested [see VanHoose (1991), for a formal analysis], would be that these policy rates would effectively establish a ceiling and a floor for the federal funds rate, potentially assisting the Fed's efforts to attain its monetary policy objectives.

In 2003, the Fed altered its policy for setting the discount rate by establishing the rate as a penalty. Initially, the Fed set the penalty as 1 percentage point above the federal funds rate, but in 2007 the Fed reduced this penalty to 0.5 percentage point. The interest fee on intraday overdrafts of reserve accounts by depository institutions, however, remains at a level that is below a rate sufficient to induce depository institutions to sharply limit their overdrafts. Nevertheless, when the Fed begins paying interest on 
reserves in 2011, key aspects of Angell's proposal effectively will go into place: a penalty rate on regular discount window loans and a rate paid on reserves set somewhat below the market federal funds rate.

When Angell's suggestion was first contemplated in the 1ate 1980s, most theoretical work by economists cast doubt on the wisdom of paying interest on reserves. For instance, Sargent and Wallace (1985) expressed concerns about potential indeterminacy issues [which were echoed in later work by Guzman (2004)]. In addition, Smith (1991) suggested the potential for a net reduction in social welfare based on an overlapping-generations analysis. Furthermore, later work by Tindall and Spencer (2000) indicated that the payment of interest on reserves would create a significant discountwindow policing problem when the discount rate is set below market interest rates.

A problem with the work of Sargent and Wallace, however, is that their indeterminacy result is based on the presumption that the rate of interest on reserves equals the market interest rate. Their indeterminacy problem vanishes when the rate paid on reserves is less than the market interest rate. In addition, work by Freeman and Haslag $(1995,1996)$ casts doubt on Smith's conclusion that paying interest on reserves would be welfare-reducing; in contrast, Freeman and Haslag conclude that an unambiguous welfare improvement would result. Finally, the Fed's switch to a penalty discount rate in 2003 eliminated the relevance of the potential policing issue discussed by Tindall and Spencer.

More recently, Goodfriend (2002) and Whitesell (2006) have provided rationales for a monetary policy based on an "interest-rate-corridor." In analyses that resurrect the ideas first discussed by Angell, these researchers suggest that taken together, a penalty discount rate and an administered 
interest payment on reserves at a rate below the market interest rate would establish upper and lower bounds for market interest rate. Goodfriend and Whitesell suggest that the result, as Angell first suggested, would be an improved capability for the Fed to smooth market interest rates in relation to its interest-rate target.

Other consequences are likely to follow from payment of interest on reserves beginning in 2011. For instance, in an interest-on-reserves environment, depository institutions will have less incentive to extend loans or obtain other traditionally interest-bearing assets. In addition, institutions are likely to reduce holdings of non-interest-bearing vault cash in favor of increased reserve balances at Federal Reserve banks. Thus, the Fed will have to determine appropriate adjustments in reserve levels to result in neutral effects on the financial system during the transition to the new regime. Furthermore, interest sensitivities of depository institutions' holdings of loans, securities, and other assets are likely to change, perhaps considerably, once interest is paid on reserves. It is likely, therefore, that Fed policy actions will exert quantitatively different effects on bank balancesheet decisions than has been true in a zero-interest setting previously had been the case. These are issues that researchers have not yet addressed but which must be better understood prior to implementation of an interest-onreserves policy in 2011.

\section{Considerations in Determining the Interest Payment on Reserves}

How should the Fed set the interest rate on reserves? To contemplate the answer to this question, let's begin by considering how the Fed funds its own operations in the present environment with no interest on reserves. The Fed issues two key liabilities: (1) non-interest-bearing currency (Federal 
Reserve notes) held by the public, and (2) total reserves of banks, which consist of vault cash and reserve deposits of depository institutions. It uses the funds it raises from issuing these liabilities to purchase assets, the large majority of which are interest-bearing U.S. Treasury securities. Thus, at present the Fed earns interest on the bulk of its assets but pays no interest on the large majority of its liabilities. The Fed uses these interest revenuestogether with fees it charges depository institutions and customers, such as the federal government, for banking and fiscal services it provides - to fund the costs it incurs in the course of its operations. These costs include the wages, salaries, and benefits of the Board of Governors and its staff and officers and staffs of the Federal Reserve banks and various other variable costs, as well as fixed capital expenses. Any remaining, unspent revenues-profits from central banking which economists call seigniorage, or taxes derived from the government issuance of money-are passed along to the U.S. Treasury, subject to oversight from Congress.

Undoubtedly, Toma and others are correct that concerns over potential reductions in seigniorage profits flowing to the Treasury lay behind past Congressional opposition to payment of interest on reserves. Now, however, reserves held at Federal Reserve banks are, as shown in Figure 1, near historically low levels. At this writing, reserves held at reserve banks account for less than 6 percent of the total of currency, vault cash, and reserves. Furthermore, market interest rates have been relatively low for more than a decade. Hence, by far the bulk of the Fed's seigniorage earnings flow from its issuance of non-interest-bearing currency. The amount of seigniorage that the Treasury stands to "sacrifice" when the Fed pays a relatively low interest rate on a small stock of reserves is likely to be a very small percentage of the Fed's total interest income. 
To be sure, when the Fed begins paying interest on reserves in 2011, depository institutions are likely to increase their voluntary reserve holdings-again, with the amount of the increase depending on exactly what rate the Fed pays. Thus, the Fed may make substantially more interest payments than would be implied by current reserve holdings in the absence of interest on reserves.

Now let's return to the question: How should the Fed set the rate of interest it will pay on reserves? Note immediately that the above discussion indicates that issues of covering Fed expenses and generating seigniorage income for the U.S. Treasury should not play any significant role in the Fed's choice of an interest payment on reserves. Any "lost revenues" from paying interest on reserves will be slight, although in principle the Fed could effectively recover these revenues by paying a slightly lower interest rate on the larger reserve balances that depository institutions are likely to hold. Indeed, by setting the rate below the market interest rate as instructed by the legislation, the Fed automatically will tend to recover any such "lost revenues."

One possible answer to the question, therefore, is that the differential between the market interest rate and the Fed's rate on reserves should be no larger than would be consistent with a recovery-at least, on average-of the interest earnings it otherwise would have gained from not paying interest on the previously smaller quantity of reserves held at Federal Reserve banks. This effectively would entail using the "revenue-neutral" rule for setting the interest rate paid on reserves.

Another issue, however, is whether the Fed should set the interest rate on reserves in a discretionary manner or allow this rate to vary automatically with another market interest rate, such as the federal funds 
rate. If the Fed opts for the former approach, then effectively it could utilize the interest rate on reserves as a changeable lower bound for an "interestrate corridor" as discussed above. Then, if the Fed wished to signal a desire for the market interest rate, say, to either remain unchanged or drift downward but not necessarily upward, it might reduce the interest rate paid on reserves.

As noted above, however, variations in the interest rate on reserves are likely to influence depository institutions' sensitivities of asset holdings with respect to changes in other market interest rates. This fact would argue against using the interest rate on reserves as a discretionary policy instrument, because changes in that rate could have impacts that would be harder to predict than suggested solely by a simple "interest-rate-corridor" analysis.

Indeed, a key factor influencing bank asset holdings when the Fed pays interest on reserves will be the spread, or differential, between the rate of return on the asset in question, such as a loan, and the rate of return earned on reserves held with the Fed. Consequently, by setting the interest rate on reserves as, say, a fixed percentage-point markdown from a market interest rate such as the federal funds rate, the Fed would do its best to minimize variations in the differential between rates of return on bank assets and the interest rate on reserves. This arguably would be the optimal policy for the Fed to pursue in setting the interest rate on reserves if it desires to minimize producing undesired redistributions of assets at depository institutions. Indeed, setting a fixed differential between the federal funds rate and the interest rate on reserves would also parallel the Fed's method for setting the discount rate since 2003.

Of course, in principle the Fed could alter a differential between the 
federal funds rate and the rate on reserves just as it altered the differential between the discount rate and the federal funds rate in 2003. Consequently, even if the Fed chooses to allow the interest rate on reserves to move with a market interest rate, in principle it can still use its discretion in determining the size of the markdown from the market rate.

\section{The Obsolescence of Reserve Requirements}

In 1988, I was a visiting economist at the Federal Reserve's Board of Governors. During that year, I attended a meeting of staff economists at the in which the following question came up: What is the fundamental rationale for reserve requirements? What immediately came to my mind were Friedman's (1960) classic discussion of the issue and related work by Baltensperger (1982). I waited, however, to hear what the full-time, career Fed economists in the room might suggest as possible answers to the question. In the end, the best rationale for reserve requirements that any of them could suggest was that reserve requirements promoted the "prestige" of the central bank.

In fact, economists have long understood that reserve requirements do not necessarily promote monetary and financial stability or, as shown by Baltensperger, broader economic stability. Indeed, reserve requirements essentially have been at best an ambiguous tool of policy and more likely a largely irrelevant tool whenever the Federal Reserve has utilized an interest rate as its main policy instrument. Only in environments in which the Fed or another central bank seeks to attain goals for levels or rates of growth of monetary aggregates can reserve requirements matter for monetary policy.

Other central banks that utilize a market interest rate as the fundamental instrument of monetary policy, such as the Bank of Canada 
and the Bank of England, long ago effectively eliminated reserve requirements. The European Central Bank continues to utilize a reserve requirement, but its required reserve ratio (which applies to virtually all transactions and savings deposits at depository institutions) is at the relatively low level of 2 percent. No other central bank in the developed world assesses a reserve requirement ratio as high as the 10 percent ratio officially maintained by the Federal Reserve but effectively rendered impotent by U.S. depository institutions' sweep accounts.

Thus, since at least the mid-1980s, the rationale for reserve requirements has indeed rested only on ideas such as promoting a central bank's "prestige" - or, stated differently and more precisely, the central bank's ability to exercise coercive control over a scarce resource. Since the advent of sweep accounts in the 1990s, however, the Fed's capability to "control" reserve levels via required reserve ratios has been virtually nil. Depository institutions have effectively dodged most of the force of the Fed's formal reserve requirements by transferring funds from officially reservable deposits to deposits not subject to reserve requirements.

Nevertheless, U.S. depository institutions incur both fixed and variable costs in managing sweep accounts, some of which are passed along to depositors in the form of lower deposit interest returns. Payment of interest on reserves is likely to reduce depository institutions' incentives to sweep funds between accounts on today's high scale. Such accounts are likely to remain in operation as long as reserve requirements remain in force, with the magnitudes of flows of swept funds depending ultimately on the size of the differential between the relevant market interest rate and the interest rate on reserves. Paying interest on reserves could help reduce the resource waste associated with sweep accounts, but this policy is unlikely to 
eliminate this waste.

Monetary policy can function effectively in the coming regime of interest on reserves. Furthermore, in this regime, depository institutions will have a greater incentive to hold reserves voluntarily. Depending on the level of the interest rate on reserves in relation to market interest rates, overall reserve balances may not decline and potentially could even increase. In any event, there is already no clear rationale for maintaining a 10 percent required reserve ratio for transactions deposits. In fact, once the Fed begins paying interest on reserves, there will be no obvious rationale for any reserve requirement.

\section{Conclusion}

Beginning in the fall of 2011, depository institutions will have a stronger incentive to hold reserves at Federal Reserve banks, because the payment of interest on reserves by the Fed will reduce the opportunity cost of each dollar held on reserve. This policy brief has examined why Congress has granted the Fed the authority to pay interest on reserves, the qualitative impacts of payment of interest on reserves upon the decisions of depository institutions, and the implications for Federal Reserve policymaking.

There has always been a compelling argument for paying interest on reserves held at Federal Reserve banks: requiring depository institutions to hold non-interest-bearing reserves imposes an opportunity cost on the institutions and their depositors. This is why economists have long suggested that reserve requirements effectively function as a tax on owners and customers of depository institutions.

The recent Congressional decision to authorize the Fed to pay interest 
on reserves promises to reduce this tax. At depository institutions, the payment of interest on reserves is likely to generate increased holdings of reserves and alter the interest sensitivities of asset holdings. In addition, growth in sweep account balances is likely to slow and could even reverse, although as long as reserve requirements are in place sweep accounts and associated resource costs of maintaining them are unlikely to disappear. Furthermore, depository institutions may respond by seeking to reduce intraday overdrafts of their reserve accounts at Federal Reserve banks, thereby reducing the Fed's exposure to payment system risks.

In principle, the payment of interest on reserves will add to the Fed's set of monetary policy tools. The penalty discount rate could establish an upper bound on market interest rates, and the interest rate on reserves could set a lower bound, hence establishing an "interest rate corridor." The Fed could either set the interest rate on reserves at an administered level that it could vary in a discretionary fashion. Alternatively, the Fed could set a differential between the federal funds rate and the interest rate on reserves, although in principle it could engage in discretionary changes in the magnitude of this differential.

Payment of interest on reserves is likely to add pressure for significant reductions in, or possibly elimination of, U.S. reserve requirements. The receipt of interest on reserves will reduce the incentive for depository institutions to economize on reserves. Depository institutions already avoid a considerable portion of the reserve-requirement "tax" through the use of sweep accounts. Consequently, ending or at least scaling back the present reserve requirement regime could have fairly small effects on total reserve balances at Federal Reserve banks. At the same time, significant cuts in reserve requirements would remove much of the 
incentive to incur wasteful resource costs required to maintain sweep arrangements.

Thus, the decision by Congress to permit the Fed to pay interest on reserves is a significant event. Once this policy change goes into effect in 2011, it is likely to have repercussions for the U.S. financial system for many years to come. 


\section{REFERENCES}

Baltensperger, Ernst. 1982. Reserve requirements and economic stability. Journal of Money, Credit, and Banking 14, 205-215.

Bernanke, Ben. 2006. Bank regulation and supervision: Balancing benefits and costs, Remarks before the Annual Convention of the American Bankers Association, Phoenix, Arizona, October 16 (www.federalreserve.gov/boarddocs/speeches/2006/20061016/default. htm).

Cynamon, Barry, Donald Dutkowsky, and Barry Jones. 2006. Redefining the monetary aggregates: A clean sweep. Eastern Economic Journal 32, 661-672.

Dixon, Alan. 1991. Interest on bank reserves makes sense. New York Times, March 25.

Dutkowsky, Donald, and Barry Cynamon. 2003. Sweep programs: The fall of M1 and rebirth of the medium of exchange. Journal of Money, Credit, and Banking 35, 263-279.

Dutkowsky, Donald, Barry Cynamon, and Barry Jones. 2006. U.S. narrow money for the twenty-first century. Economic Inquiry 44, 142-152.

Ennis, Huberto, and John Weinberg. 2007. Interest on reserves and daylight credit. Federal Reserve Bank of Richmond Economic Quarterly 93 (Spring), 111-142.

Federal Reserve Task Force on Payment System Risks. 1988. Report. Freeman, Scott, and Joseph Haslag. 1996. On the optimality of interestbearing reserves in economies of overlapping generations. Economic Theory 7, 557-565.

Freeman, Scott, and Joseph Haslag. 1995. Should bank reserves earn interest? Federal Reserve Bank of Dallas Economic Review, $4^{\text {th }}$ Quarter, 
25-33.

Friedman, Milton. 1960. A Program for Monetary Stability. New York: Fordham University Press.

Goodfriend, Marvin. 2002. Interest on reserves and monetary policy. Federal Reserve Bank of New York Economic Policy Review 8 (May), 16.

Guzman, Mark. 2004. The impact of paying interest on reserves in the presence of government deficit financing. Federal Reserve Bank of Dallas Research Department Working Paper 04-06.

Jones, Barry, Donald Dutkowsky, and Thomas Elger. 2005. Sweep programs and optimal monetary aggregation. Journal of Banking and Finance 29, 483-508.

Jones, Barry, Adrian Fleissig, Thomas Elger, and Donald Dutkowsky. Forthcoming. Retail sweep programs and monetary asset substitution. Economics Letters.

Kanatas, George, and Stuart Greenbaum. 1982. Bank reserve requirements and monetary aggregates. Journal of Banking and Finance 6, 507-520.

Liviatan, Nissan, and Roni Frish. 2006. Interest on reserves and inflation. Journal of Development Economics 80, 269-274.

McCallum, Bennett, and James Hoehn. 1983. Instrument choice for money stock control with contemporaneous and lagged reserve requirements. Journal of Money, Credit, and Banking 15, 96-101.

Miller, G. William. 1978. Statement to U.S. House of Representatives Committee on Banking, Finance, and Urban Affairs. Federal Reserve Bulletin 64, 636-642.

New York Times. 1991. Capital Games, March 10.

Proxmire, William. 1978. Letter to G. William Miller. Senate Committee on 
Banking Housing, and Urban Affairs, May 9.

Reuss, Henry, and William Proxmire. 1978. Letter to G. William Miller. House Committee on Banking, Finance, and Urban Affairs and Senate Committee on Banking, Housing, and Urban Affairs. June 5.

Sargent, Thomas, and Neil Wallace. 1985. Interest on reserves. Journal of Monetary Economics 15, 279-290.

Smith, Bruce. 1991. Interest on reserves and sunspot equilibria: Friedman's proposal reconsidered. Review of Economic Studies 58, 93-105.

Thornton, Daniel. 1988. The borrowed-reserves operating procedure: Theory and practice. Federal Reserve Bank of St. Louis Review 70, 3050.

Tindall, Michael, and Roger Spencer. 2000. Central bank reserve management: Aggregate targets and interest payments on reserves. International Advances in Economic Research 6, 178-191.

Toma, Mark. 1999. A positive model of reserve requirements and interest on reserves: A clearinghouse interpretation of the Federal Reserve System. Southern Economic Journal 66, 101-116.

VanHoose, David 1991. Bank behavior, interest rate determination, and monetary policy in a financial system with an intraday federal funds market. Journal of Banking and Finance 15, 343-365.

VanHoose, David 1990. Borrowed reserves targeting and nominal income smoothing. Journal of Macroeconomics 12, 263-278.

VanHoose, David. 1986. A note on interest on requires reserves as an instrument of monetary control. Journal of Banking and Finance, 10, 147-156.

VanHoose, David, and David Humphrey. 2001. Sweep accounts, reserve management, and interest rate volatility. Journal of Economics and 
Business 53, 387-404.

Weiner, Stuart. 1985. Payment of interest on reserves, Federal Reserve Bank of Kansas City Economic Review 70 (January), 16-31.

Whitesell, William. 2006. Interest rate corridors and reserves. Journal of Monetary Economics 53, 1177-1195. 
